Journal of Social Sciences (COES\&RJ-JSS)

ISSN (E): 2305-9249 ISSN (P): 2305-9494

Publisher: Centre of Excellence for Scientific \& Research Journalism, COES\&RJ LLC

Online Publication Date: 1st October 2018

Online Issue: Volume 7, Number 4, October 2018

https://doi.org/10.25255/jss.2018.7.4.358.365

\title{
Pragmatic Approach: Lexical Presupposition in King Abdullah II Political Speech
}

\author{
Mheel AL-Smaihyeen \\ Lecturer, Faculty of Foreign Languages, English Language and Literature, \\ University of Jordan \\ Faculty of Languages and Communication, \\ Universiti Sultan Zainal Abidin \\ Gong Badak Campus, Terengganu, Malaysia \\ Email: Mheel.Alhwetat84@gmail.com
}

\&

Mohd Nazri bin Abdul Latiff

Faculty of Languages and Communication Universiti Sultan Zainal Abidin

Gong Badak Campus, Terengganu, Malaysia

mohdnazri@unisza.edu.my

\begin{abstract}
:
The purpose of this study is to cast the light on the lexical presupposition in political speech by King Abdullah II of Jordan. The lexical presupposition is one of the primary concepts of pragmatics, and it is used to include a general class of pragmatic and semantic phenomena that have a fundamental impact on the apprehension of utterances. Particularly, this concept denotes premise that truth is taken in an utterance and without the value of truth that cannot be set and can broadly be related with a lexical element or certain grammatical features in any utterance. The language plays a significant role in the communication and interpretation of intentions by examining selected political speeches of King Abdullah II in European Parliaments Strasbourg in 2015 and his speech at the Leaders' Summit on Refugees (on the margins of the 71st UN General Assembly) that held in New York in 2016. Generally, political speech involves a language that is padded to be understood only by political people or people who have knowledge in political speeches whose language tends to be ambiguous and implicit meaning. Thus, this study glosses the lexical presupposition in King Abdullah II political speech. It finds the lexical presupposition in his speech and the reason for using lexical presupposition in his speech.
\end{abstract}

Keywords:

Pragmatics, Presupposition, Political Speech, Lexical Presupposition

\section{Citation:}

AL-Smaihyeen, Mheel; Abdul Latiff, Mohd Nazri bin (2018); Pragmatic Approach: Lexical Presupposition in King Abdullah II Political Speech; Journal of Social Sciences (COES\&RJJSS), Vol.7, No.4, pp:358-365; https://doi.org/10.25255/jss.2018.7.4.358.365.

This work is licensed under a Creative Commons Attribution 4.0 International License. 


\section{Introduction}

King Abdullah II delivered a number of speeches in many international forums in the economic, political and other fields. His Majesty King Abdullah II is one of the most experienced people in the field of political discourse. He is capable of directing implicit messages that can be understood and understood by experts and specialists. He sometimes uses pragmatics in his speech to convey a message that he does not want to be understood by all, this indicates his eloquent and linguistic ability in speech.

Language and politics are related, so language is the way by which political thoughts are spread to the society (Harris, 1984). In politics, words have a highly impact, and they have the force to create an action or an idea un/justifiable. They can promote feelings in the listeners to recognize a phenomenon as thankworthy or unworthy. Also, they have the great power to be more effective and persuasive for audience. Therefore, a professional politician have to be able to get benefits these characters in his/her speech and attempt to favorably use them according to his/her wants and needs to attract the attention and provoke the emotion of the audience (Mazlum, 2016). Many concepts of pragmatics used in political speech such as implicature, presupposition, and deixis. The overarching objectives of this article are to explicate and analyze lexical presupposition in King Abdullah II political speech, and find the main drawbacks in apprehending political speech.

\section{Theoretical Background}

Pragmatics goes over "the characterization of contextual aspects that help to identify any proposition expressed by a particular sentence" (Stalnaker, 1972). One of the most important concepts of pragmatics is presupposition that means inexplicit meaning that conveyed by a speaker or a writer by using certain words. Examples are given in $(A, B)$ : The presupposition of each sentence explained below the sentence.

A. The King of Jordan is brave. The implicit assumption that could be understood in this sentence is Jordan has a king and its king is unique and courageous.

B. Susann knows that Edison invented the electric light. The inexplicit assumption here is that Edison invented the electric light.

Presupposition was a core of the linguistic issue during the period 1969 to 1975. Basically, it is used in the philosophy of logic refers to a certain kind of inexplicit information (Hashim, 2009). In a few years ago, pragmatics has focused on the task of presupposition in growing discourse and the use of presupposition to achieve certain effects on communication (Thorn borrow \& Wareing, 1998; Marmaridou, 2000). Presuppositions are essential elements of meaning that must be presumed, recognized, understood and accepted as a matter of course (Verschueren, 1999; Fasold \& Linton, 2006; Bajnaid et al., 2018).

Presupposition has a plethora of types such as existential, structural, and lexical, to name but a few. Banjar (2009) figured out existential presupposition is the presuming of the presence or existence of the entities called by the speaker. For example, when the speaker says "John's daughter is cute" we can presuppose John has a daughter. On the 
other hand, she pointed out that structural presupposition is the presumption related with the using some words and phrases. For instance, wh-question construction in English language are generally interpreted with the assumption that the information after the wh-question (e.g. where and when) is previously recognized to be the case. Examples are provided in $(1,2)$.

1. When did the king of Jordan deliver a speech? The implicit meaning that can be understood by structural presupposition is the king of Jordan delivered a speech.

2. From where did Edward receive the bad news? The inexplicit meaning is Edward received the bad news a phone. When it comes to lexical presupposition, Yule (1996) illustrated lexical presupposition by indicating that in saying one succeeded to do something; the verb 'succeed' carries confirmed and presumed meaning. The confirmed meaning is that the person managed to do something. Consequently, in saying one did not succeed to do something, the confirmed meaning is that the person did not manage, whereas the presumed meaning (non-confirmed) is that the person attempted to do that something. For this reason, 'succeed' is generally interpreted as confirming 'manage' and presuming 'attempted'. Levinson, (1983) described this kind of verbs as 'implicative verbs' providing the following examples:

A. Michal succeeded to get political asylum.

B. Michal attempted to get political asylum.

C. Michal forgot to ask political asylum when he arrived America.

D. Michal should ask and get political asylum.

In the examples above, using the verb 'succeeded' in ' $A$ ' presupposed that he got political asylum whereas using 'attempt' verb in ' $B$ ' assumed that he did not get political asylum. Also, using some verbs like ' forgot' indicates that he did not get political asylum and a verb such as 'should study' denotes that he did not get political asylum.

\section{Literature Review}

\subsection{Pragmatic Approach and Political Speech}

Pragmatics is the study of the use of language in special contexts or situations of necessity, and this would take into account the message being communicated or the act of speech is performed. Participation of participants; their intention, knowledge of the world and their impact on their interactions; what they considered to be recognized as part of the context; their discounts on the basis of context; what involved what was said or left unpaid; etc. (Leech, 1983). Some politicians do not recognize the fact that there is a relation between what actually is said, what is meant, and the action conveyed by what is said.

Pragmatics deals with how language elements, concepts, and contextual factors work together to interpret particular texts or utterances, and enabling the listener/reader to get the right or intended meaning of the speaker/writer instead of following the reference meaning of a word. Pragmatics examines "the characterization of contextual aspects that help to identify any proposition expressed by a particular sentence" (Stalnaker, 1972). Because the pragmatic approach leans on decoding the implicit 
meaning of the text, it can report the role of the target reader in the process of meaning creation (Boase-Beier, 2014).

Pragmatics has a crucial role in the creation of efficient political speech strategies. Political speech is kind of a message by any politician that is generally a president, a king or a candidate representative of a political function. Political language should convey the clear message to the audience by a solid language to be persuasive and effective to readers or listeners. Strong political speech is what leaves an impact on listeners/readers and it will be strong when it is purposeful and provocative, and it is clear that politicians generally resort to the use of pragmatics in all its forms. Politicians are good at playing with words in using the language to connect to their purpose without explicitly stating the meaning, but it can be understood through the context.

\subsection{The Previous Studies}

Several studies have been conducted in pragmatics in analyzing political speech such as Zglobiu (2015) conducted a study in pragmatics elements and political speech and figured out the role and the importance of pragmatic elements in political speech. Also, he raised the significant role in "building up" strong core of political speech from linguistic prescriptive. Furthermore, Zglobiu pointed out that the language of political discourse needs an experienced and highly educated person and his ability to use language effectively. Youssef (2015) illustrated how politicians use pragmatics in delivering a speech in order to fulfill variant purposes, involving sending and passing effective messages to the audience by using presupposition. Many scholars investigated how pragmatics used in the political speech, especially deixis, implicatur, and speech act. In this research, the researcher will analyze and show the effects of using lexical presupposition in political speech that have been tried deeply before.

\section{Methodology}

In this research, two political speeches were chosen by King Abdullah II in European Parliaments Strasbourg in 2015 and his speech at the Leaders' Summit on Refugees (on the margins of the 71st UN General Assembly) which was held in New York on 20 September 2016. The excerpts of these speeches were downloaded from King Abdullah official Website. These speeches were selected due to their popularity. There are lots of theories and methodologies that can be adopted in this kind of study. In the current study, the linguistic approach adopted is leaned on the linguistic framework of presupposition theory of Stalnaker (1978) and Yule (1996).

In the current study, the researcher adopted analytical approach that depends on descriptive qualitative method. The political speech by King Abdullah II will be analyzed in terms of lexical presupposition. The political speech will be analyzed by lexical presupposition in several procedures. First, words that have inexplicit meaning will be identified and analyzed. Second, the researcher will explain the intended meaning that did not mention directly in his political speech. Finally, the researcher will comment why the King Abdullah II used lexical presuppositions in his speech. 


\section{Analysis and Discussion}

The analysis of this study draws on presupposition theory of Stalnaker, the political text analyzed to get the intended meaning. In the following excerpts from Abdullah's political speech II in European Parliaments Strasbourg in 2015, in this speech lexical presupposition will be explained.

Excerpt No. (1):

"The savage murder by Daesh of Jordan's hero pilot outraged all Jordanians, and horrified the world. Jordan's response has been swift, serious and determined. And our fight will continue".

In this excerpt, it is noted that the king in his speech used lexical presupposition in last sentence "and our fight will continue", he means here Jordan was frightening Daesh before and the will continue their fighting in the future. He did not mention that in explicit form, he implied by fighting that Jordan was fighting terrorism in the past, Jordan is fighting terrorism now, and Jordan will fight the terrorism in the future.

Excerpt No. (2):

"More than a thousand years before the Geneva Conventions, Muslim soldiers were ordered not to kill a child, a woman or an old person, not to destroy a tree, not to harm a priest, not to destroy a church".

The king used presupposition to tell the addressees that all things that they are talking about now are prohibited in Islam before the Geneva Conventions, and he said killing a child, a woman or an old person, destroying a tree, harming priest, and destroying a church are illegal in Islam religion before the Geneva Conventions.

It is worth noting that he wants to indicate that real Islam is the religion of justice and respecting others, not the religion of killing and vandalism.

Excerpt No. (3):

"But co-existence must be made, and made again, in every generation. The common good is defended only by vigilance and action. This means more than security measures. Humanity must arm itself with ideas, with justice and with economic and social inclusion. In this excerpt, he clarifies there was co-existence before, and he used ' again' is taken to presuppose another unstated concept.

Excerpt No. (4):

"Europe is an important partner in this effort - especially in helping to stop the global rise of Islamophobia. This poison is based on false ideas and plays into the hands of these extremists".

King Abdullah II indicates the Islamophobia was rising due to lots of factors. Using the word 'stop' implies it is still rising.

King Abdullah II delivered a speech at the Leaders' Summit on Refugees in New York on 20 September 2016. In his speech, he talked about Syrian war effects on Jordan. 
Excerpt No. (1):

"In the past five years the Syrian crisis has sent Jordan's burden skyrocketing. Some 2.5 million Syrians have crossed into Jordan since 2011. Today we are hosting 1.5 million Syrians, one for every five of our own citizens".

The king implied in this excerpts that Jordan has a problem before the Syrian crisis but this crisis leads to increasing Jordan's burden skyrocketing. He did not mention that Jordan has a crisis in economic explicitly, but he used presupposing to clarify his ideas.

Excerpt No. (2):

"For many years, our country's security and stability and our citizens' generous compassion have led desperate refugees to our doors".

In this excerpt, his majesty refers that Jordan has many other refugees not only Syrian refugees, but Jordan has refugees from several parts of the world such as Palestine, Iraq, Lebanon, to name but a few.

Excerpt No. (3):

"My final point is that a truly sustainable solution should begin by safeguarding Syrian women and children from being used by Daesh and other terrorist organizations, which are manipulating human trafficking and taking advantage of the movement of displaced groups".

The king here implied that Syrian people were suffering and still. They are suffering from oppression; Syrian women are raped and children and elderly people are killed.

\section{Conclusion}

Generally, Kings and presidents use pragmatics in their speech especially political speech to be more effective and impressive. Using pragmatics in speech gives strong evidence that the speaker has knowledge, and the ability to convince others in his/her opinions. This study investigates the analysis of King Abdullah II political speech and it figures out the presupposed or assumption meaning. This study is employed to find the lexical presupposition in his political speech. He has the ability to effects listeners because his speech is sophisticated and impressive. He resorted to pragmatics to invoke the listener or the readers, especially decisions maker. This study comes up with findings that reveal his Majesty avoids sometimes using explicit speech, and tends to use implicit speech that has more effect on the listeners and the readers. He used lexical presupposition in his political speeches to convince others about certain issues or could be to avoid insulting others.

This study is applied on King Abdullah II speech because he is one of the most effective leaders in the Middle East, and he is known eloquent in delivering speeches in conferences, meetings and many occasions. 


\section{Pragmatic Approach: Lexical Presupposition in King Abdullah II Political Speech}

\section{References}

Austin J. L. 1962. How to do Things with Words, Oxford: Oxford University Press.

Bajnaid, A., Veltri, G., and Elyas, T. 2018. Utilizing Matrimonial Web sites Among Saudi Users: An Empirical Study. Digest of Middle East studies, 1-30.

Banjar. S .2009. Presupposition and Entailment, Department of English Jeddah/ Saudi Arabia.

Beard Adrian, 2000. The Language of Politics, New York: Routledge.

Boase-Beier, J. 2014. Stylistics and Translation. In: M. Burke, ed. The Routledge Handbook of Stylistics. London and New York: Routledge, pp.393-407.

Chilton P. 2004. Analyzing Political Discourse: Theory and Practice, London: Routledge.

Fasold, Ralph W., and Linton, Jeff Connor. 2006. An Introduction to Language and Linguistics. Cambridge: Cambridge University Press.

Harris, S. 1984. Questions as a mode of control in a magistrate's court. International Journal of the Sociology of Language, 49, 5-27.

Hashim.S. 2009. Existential Presupposition in Religious Islamic Texts: Pragmatic Implications. University of Sulaimani/ Iraq.

Hazlett, A. 2010. Factive Presupposition and the Truth Condition on Knowledge, 78:3, pp.

Grundy, P. (2000). Doing Pragmatics, New York: Arnold.

Leech. J. 1983. Principles of Pragmatics, New York: Rutledge.

Levinson, S. 1983. Pragmatics. Cambridge: Cambridge University Press.

Marmaridou, Sophia S. A. 2000. Pragmatic Meaning and Cognition. Amsterdam: John Benjamins Publishing Company.

Mazlum. F. 2016. Evaluative Language in Political Speeches: A Case Study of Iranian and American Presidents' Speeches.

Searle J.R. 1969. Speech Acts, Cambridge: Cambridge University Press.

Simpson, P., and Mayr, A. 2010. Language and Power, London: Routledge.

Smith, N. V. (ed.) 1982. Mutual Knowledge. London: Academic Press.

Stalnaker, R. 1972. Pragmatics. In: Davidson, D. and G. Harman, eds. Semantic of Natural Language. Dordrecht: Reidel. 
Thomas J. (1995). Meaning in Interaction: An Introduction to Pragmatics, New York: Longman.

Thornborrow, Joanna and Wareing Shan. 1998. Interface Patterns in Language: An Introduction to Language and Literary Style. Oxford: BlackwellPress.

Van Dilk and Teun A. 1997. What is political discourse analysis?, in: J. Blommaert and C. Bulcaen (Eds.), Political Linguistics,

Verschueren, Jef. 1999. Understanding Pragmatics. New York: Oxford University

Watson J. R. and Hill A. 1993. A Dictionary of Communication and Media Studies, London: Edward Arnold.

Youssef. S. 2015. A Pragmatic Analysis of Presupposition Use in Political Discourse: Obama's Speech on ISIL. Helwan University.

Yule, G. 1996. Pragmatics. Oxford. Oxford University Press.

Zglobui. A. 2015. Elements of Pragmatics in Political Discourse. Studia Ubb Philologia, LX, 2. 